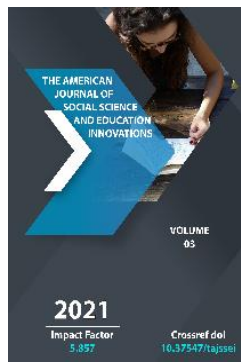

\title{
Interconnection Of Moral And Economic Education
}

\section{Barno Khodjimuratova}

Senior Teacher Of The Tashkent State Pedagogical University, Tashkent, Uzbekistan

Journal Website:

http://usajournalshub.c

om/index,php/tajssei

Copyright: Original content from this work may be used under the terms of the creative commons attributes 4.0 licence.

\section{ABSTRACT}

This article presents additional tasks that contribute to the moral and economic education of older preschool children.

\section{KEYWORDS}

Economy, economy, labor, money, value, price, frugality, honesty, economy, dignity, generosity, moral education.

\section{INTRODUCTION}

Economics literally means the art of housekeeping. Obviously, the "art of housekeeping" also provides for the care of this "household", its protection and protection. Consequently, already starting from preschool age, children need to be given knowledge about what is the key to correct "housekeeping", and not only to form ideas about economic categories. That is, it is necessary to acquaint children with the relationship of economic and ethical categories: "labor", "money", "value", "price", on the one hand, and moral - "thrift", 
"honesty", "economy", "dignity" , "Generosity" - on the other.

Unfortunately, these basic economic qualities inherent in a person - the owner, every year lose their authority among young people. In this connection, the question arises of increasing the effectiveness of the moral and economic education of children from preschool age.

Under "moral education" is understood the purposeful process of the formation of the rising generation of high consciousness, moral feelings and behavior in accordance with the ideals and principles of public morality.

According to psychologists (B.G. Ananiev, S.L. Rubinstein, L.S.Vygotsky), on the border of preschool and school ages, there is, as it were, a closing of ties between the two most important spheres of life - the world of human relations and the objective environment. It was during this period that a leap took place in the formation of the personality, its basic psychological foundations. The child's activity in the systems "child - public object" and "child - public adult" represent a single process in which the personality of the child is formed.

\section{MATERIALS AND METHODS}

According to research data, the inclusion of preschoolers in more complex, socially assessed types of activity proceeds more successfully if the moral side is highlighted in them from the very beginning, since inclusion in an activity is an initiation into a business that has its own goal, the achievement of which is beneficial as a subject. activities, and to other people, society as a whole.
As you know, the development of consciousness and activity are interdependent. Forming in activity, consciousness then manifests itself in the attitude of a person to activity, directs it, makes it expedient, motivated (L.S. Rubinstein, L.S.Vygotsky, A.N.).

There is a close connection between all aspects of education in the process of personality development. Moreover, the interrelation of moral, labor and economic education is also substantiated. The core in this interconnection of the parties is moral education. It was he who was nominated by V.G. Belinsky to the fore, revealing the tasks of a reasonable upbringing. In his opinion, the yardstick of morality is not words, but practical activity: "the sphere of morality is primarily a practical sphere."

Sasova I.A., Vasiliev Yu.K., Shemyakin B.P. and others determined that already at preschool age it is possible and necessary to develop a sense of the owner with the inherent qualities of economic activity (thrift, frugality, rationality, efficiency). Therefore, speaking about the importance of the upbringing of qualities corresponding to the image of "man the owner", it is necessary to note the line of interrelation between economic and moral upbringing. Shatova A.D. for the first time in her book, she raised the issue of the moral and economic education of children, referring to the interpretation of this concept by Amend A.F.

Amend A.F. and his students tried to combine these 2 types of upbringing and highlight the personal quality, to the formation of which they strive - this is moral and economic upbringing. 
Under the "moral and economic education" is understood the integrative quality of the individual, expressed in the ability of students to participate in economic relations, focusing on generally accepted moral standards, as well as in the readiness to achieve their own economic goals and success, taking into account moral values.

\section{RESULTS AND DISCUSSION}

Analysis of the definition suggests that not all of its content is fully feasible at preschool age, since children still do not set their own economic goals. Basically, we are faced with the task of teaching a child to "participate in economic relations, focusing on generally accepted moral norms" Knowledge about moral norms should be combined with the formation of moral qualities in preschoolers. For a long time, one of the most authoritative qualities of economic activity in the theory and practice of education was thrift. However, it was never evaluated from the standpoint of economic content, but mainly as a moral quality (Godnik S.M., Kiyan L.F.Bobyleva L.D., Ryabinina N.P. and others). The economic conditionality and the above-mentioned qualities, such as economy, hard work, and prudence, were ignored, although many personality traits "should be considered different sides of a single whole," as N.P. Ryabinin. Studying the problem of education of frugality Zhukovskaya R.I. came to the conclusion that one of the most effective ways of fostering respect for toys and books is to foster interest in them. But thrift is not only about caring for toys and books.

It is customary to understand frugality as the moral quality of a person, which is expressed in a prudent attitude towards material and spiritual values, in the ability to use these values expediently. Thrift is an indicator of a person's spiritual culture.

Thrift - irreconcilability to waste, mismanagement. Every thing in the house is the work of many people, therefore, in relation to things, objects, an attitude to work, to people, to the whole of society is also manifested. A disciplined person is always thrifty. He saves his own and other people's time, he is accurate in everything.

Teachers and parents can prove to children by word and deed that nothing can be given to a person without labor. Children should be participants in the distribution of the family budget. It is necessary to involve them in the search for a reserve of savings: how to save electricity, water, bread, etc. The task of education of frugality was posed in the first program documents of kindergartens. They were about fostering a respectful attitude in children to the surrounding material, objective world: to toys, books, animate and inanimate nature, to everything that surrounds the child.

We will find the same when analyzing complex programs, such as "Development", "Rainbow", "Origins", "Childhood", "Program of education and training in kindergarten", "Parma" of all these programs, only in the programs "Parma" and "Origins" presents additional tasks that contribute to the moral and economic education of older preschool children. This program includes a section "Economic education", where it is indicated: - to form knowledge about a thrifty, economical, good owner.

In the program "Origins" in the section "The world we live in" the following tasks are heard: 
to teach children to take care of animate and inanimate nature, to anticipate in advance the positive and negative consequences of their intervention, to form a consumer attitude to nature; holistically, not to waste natural resources; to form the first skills of rational use of natural resources teach to economically use water, paper, plasticine, clay form ideas about the role of money, about the need to think about what you can spend money on, and what you should not form an idea about how to wash and clean clothes, which methods are more economical;

What devices help to save natural raw materials;

What to look for when buying things in a store;

The objectives of this program most widely reveal the objectives through which moral qualities are formed;

But in addition to these programs, there are also special programs for economic education. This is the program "Preschooler and Economics", the author of which is Shatova A.D. This program is designed to work with children of older preschool age and sets the following tasks:

- To understand and appreciate the surrounding objective world (the physical world as a result of human labor)

- To respect people who know how to work well and earn money honestly, to be aware of the interconnection of the concepts of "labor" - "product" "money" and "the cost of a product depending on its quality" at a level accessible to him,
- To see the beauty of human creation, to recognize as authoritative the qualities of a person - the owner, who have lost their ethical and economic significance today, thrift, frugality to behave correctly in real life situations, to develop reasonable needs.

Shatova A.D. notes that a "good master" is a person who knows how to use income correctly in the interests of the family, manage the family budget, who does not spend anything in vain.

\section{CONCLUSION}

"In kindergarten and at home it is necessary to educate children with useful habits and reinforce them on a daily basis: to use carefully everything that is given for games and activities; show children an example of decent behavior in everyday life (attitude to water, light, things, etc.). As we can see, Shatova A.D. distinguishes, along with others, 2 main qualities: thrift and frugality. At the same time, these qualities can be taken as basic in the moral and economic education of preschoolers. The program is based on an integrated approach to the development of the personality of a preschooler, provides for a close connection of ethical, moral, labor and economic education. The goal of modern education is the development of those personality traits that are necessary for her and society to be included in socially valuable activities.

As Ryabinina NP states: "thrift, thriftiness, efficiency, prudence, enterprise and other qualities of a person as a bearer of economic relations and productive force should be transformed into socio-psychological and 
moral qualities. This will ensure the unity of economic education and moral education. The emergence of an economically literate and morally stable generation will provide moral immunity to the influence of negative factors of the social environment and social resilience.

\section{REFERENCES}

1. Musaeva S.I. Primary school students of the quality of frugality in the process of labor education: Abstract of the thesis. ... Candidate of Pedagogical Sciences. - T .: 1993 -- 22 p.

2. Shatova A.D., Strunilina N.A. Some aspects of the methodology of economic education of preschoolers / J. Preschool education. - M .: 1996 77. Shatova A.D. Economic education of preschoolers / Teaching aid. - $M$.: Pedagogical Society of Russia, 2005 .- 244 p. 